\title{
PERSEPSI SISWA TERHADAP DAYA JUANG MEREKA SERTA POLA ASUH ORANGTUA DAN GURU DI SD BERAKREDITASI A DAN C DI KABUPATEN BANTUL DAN BONE BOLANGO*)
}

\section{STUDENTS' PERCEPTION ON THEIR ADVERSITY QUOTIENT AND PARENTING OF PARENTS AND TEACHERS IN PRIMARY SCHOOLS ACCREDITED A AND C IN THE DISTRICTS OF BANTUL AND BONE BOLANGO}

\author{
Nur Listiawati \\ Pusat Penelitian Kebijakan Pendidikan dan Kebudayaan \\ Gedung E Lantai 19, Balitbang Kemendikbud \\ Jl. Jenderal Sudirman - Senayan Jakarta Pusat \\ e-mail: n.listiawati07.@gmail.com
}

Naskah diterima tanggal: 03-11-2016, Direvisi akhir tanggal: 22-12-2016, disetujui tanggal: 30-12-2016

\begin{abstract}
This study aims to examine students' perception of their parents and teacher in instilling and developing students potential to improve their adversity quotient and students' perception on their adversity quotient. This study is a case study carried out in two A and C accredited primary schools each in Bantul District and Bone Bolango District. Measurement of parenting used the inventory method. Measurement of students' adversity quotient was conducted by the self-inventory method. Study result shows that accredited A primary school students' perception on the parenting of parents and teachers and their adversity quotient in general are better than students' perception of accredited C primary school. Parents cognitive abilities affect their ability to guide their children in analyzing and limit problems. The ability of teachers in the aspect of listening is lower than other aspects, namely, guiding to explore, analyze, and do something. Parenting from parents and teachers contribute to develope students adversity quotient significantly. However, it is only for few aspects such as guiding to explore, analyze, and do something that influenced. Even in sample schools located in Bantul, partially there is no aspect of teachers parenting that contributed to students adversity quotient. Perceptions of students in Bantul on their adversity quotient is generally higher than students in Bone Bolango. The study concludes that parents cognitive ability affect their ability to guide their child to analyze and isolate the problem. Growing and developing students' adversity quotient will be more meaningful if collaboration between teacher and parents is improved.
\end{abstract}

Keywords: students' adversity quotient, parenting, teacher's parenting, students' perception

\begin{abstract}
Abstrak: Studi ini bertujuan untuk mengkaji pola asuh orang tua dan guru dalam menumbuhkan potensi daya juang siswa dan persepsi siswa terhadap potensi daya juang mereka. Studi ini merupakan studi kasus yang dilakukan di dua sekolah berakreditasi $A$ dan C masing-masing di Kabupaten Bantul dan Kabupaten Bone Bolango. Pengukuran pola asuh orangtua dan guru menggunakan metode inventory. Pengukuran persepsi siswa terhadap potensi daya juang mereka dilakukan dengan metode self inventory. Hasil kajian menunjukkan bahwa secara umum persepsi siswa terhadap pola asuh orangtua dan guru serta daya juang siswa di sekolah berakreditasi A lebih baik daripada persepsi siswa di
\end{abstract}

*) Penelitian ini adalah bagian dari Penelitian Kajian Penumbuhan Karakter yang dilakukan oleh Pusat Penelitian Kebijakan Pendidikan dan Kebudayaan yang bersumber pada APBN 2016. 
sekolah sampel berakreditasi C. Kemampuan kognitif orangtua memengaruhi kemampuan membimbing anak untuk menganalisis dan membatasi masalah. Kemampuan guru dalam aspek mendengarkan lebih rendah daripada aspek lainnya yakni membimbing untuk mengeksplorasi, menganalisis dan membatasi masalah, serta bertindak. Pola asuh orangtua dan guru memberikan kontribusi pada penumbuhkembangan potensi daya juang siswa. Namun, secara parsial hanya aspek membimbing untuk mengeksplorasi,menganalisa masalah, dan bertindak yang memengaruhi. Bahkan, pada SD sampel yang berada di Kabupaten Bantul secara parsial tidak ada aspek pola asuh guru yang berkontribusi secara signifikan pada penumbuhkembangan potensi daya juang siswa. Persepsi siswa di Kabupaten Bantul terhadap potensi daya juangnya secara umum lebih tinggi dibandingkan siswa di Kabupaten Bone Bolango. Studi ini menyimpulkan bahwa kemampuan kognitif orangtua memengaruhi kemampuan membimbing anak untuk menganalisis dan membatasi masalah. Penumbuhkembangan daya juang siswa lebih bermakna jika kolaborasi antara guru dan orangtua lebih ditingkatkan.

Kata kunci: daya juang siswa, pola asuh orangtua, pola asuh guru, persepsi siswa

\section{PENDAHULUAN}

Kehidupan manusia diibaratkan seperti perjalanan menuju ke suatu tujuan, jika kita melewati jalan yang bagus, maka perjalanan akan lancar tanpa ada rintangan. Sebaliknya, jika kita melewati jalan berlubang maka kita perlu melakukan strategi agar tidak terperosok ke dalam dan akhirnya kita tidak dapat melanjutkan perjalanan. Pemilihan jalan yang ditempuh harus melewati proses eksplorasi dan analisis agar sampai ke tujuan dengan selamat. Demikian juga jika menghadapi persoalan, harus dipikirkan dengan matang melalui proses eksplorasi untuk memahami apa yang dihadapi dan sumber masalahnya, kemudian dilakukan analisis untuk mengatasi masalah tersebut. Masalah yang dihadapi diupayakan tidak memengaruhi sisi kehidupan yang lain atau melebar sehingga memengaruhi aspek-aspek kehidupan lainnya. Pembekalan kepada seorang anak untuk dapat menghadapi dan mengatasi setiap masalah perlu diberikan, baik dari orang tua atau keluarga maupun guru di sekolah melalui pola asuh yang dapat menumbuhkembangkan kemampuan menyelesaikan masalah.

Rencana Strategis (Renstra) Kementerian Pendidikan dan Kebudayaan Tahun 2015-2019 dalam sub tema "Permasalahan dan Tantangan Pembangunan Pendidikan dan Kebudayaan Periode 2015-2019" (Kemendikbud, 2015) me- nyatakan bahwa terdapat kecenderungan penurunan daya juang dan budaya kerja (etos kerja) serta sikap tenggang rasa dan toleransi terhadap perbedaan yang dapat memicu terjadinya konflik sosial. Pusat Penelitian Kebijakan Pendidikan dan Kebudayaan mengungkap rendahnya pola asuh orang tua dalam pemenuhan kebutuhan akan stabilitas di delapan kabupaten/kota di lokasi penelitian (Pusat Penelitian Kebijakan Pendidikan dan Kebudayaan, 2015). Pemenuhan stabilitas pada pola asuh orang tua ditandai dengan adanya keluarga yang utuh, emosi orang tua yang stabil, dan pola asuh yang konsisten. Pemenuhan stabilitas ini bertujuan untuk menciptakan keluarga/ lingkungan yang stabil sehingga anak dapat tumbuh-kembang secara optimal. Ketidakstabilan dapat menyebabkan stres, perasaan tidak aman, dan cemas, serta ketidakmampuan mengontrol kehidupan. Ketidakstabilan berdampak pada ketidakmampuan seseorang dalam membuat keputusan yang berorientasi pada masa depan (Webley \& Nyhus, 2006). Kondisi tersebut berkaitan dengan kemampuan seseorang memandang dirinya sendiri di masa mendatang, di mana gambaran itu membantu menempatkan dan mengarahkan dirinya untuk mencapai apa yang ingin diraihnya (Nurmi dalam Lestari, 2014). Sementara itu, Rahmah (dalam Lestari, 2014) menyatakan bahwa daya juang 
Nur Listiawati, Persepsi Siswa Terhadap Daya Juang Mereka Serta Pola Asuh Orangtua dan Guru Di SD Berakreditasi A dan C di Kabupaten Bantul dan Bone Bolango

merupakan kemampuan dan kegigihan mempertahankan atau mencapai sesuatu di masa depan. Dengan demikian, dapat dikatakan bahwa pola asuh orangtua dalam memenuhi kebutuhan siswa akan stabilitas memengaruhi daya juang siswa. Ketidakstabilan pada anak biasanya berkaitan dengan hubungan dalam keluarga inti, orangtua yang kehilangan pekerjaan atau harus mengubah pekerjaan menyebabkan perubahan pada jaringan sosial dan sistem dukungan yang dimiliki, serta akses terhadap fasilitas publik (Adams \& Dubay, 2014).

Sementara itu, pendiri Center of Motherhood dan Rumah Moral Melly Kiong menyatakan bahwa generasi muda sekarang memiliki kecakapan mengatasi permasalahan yang rendah (Noviarni, 2015). Lebih lanjut dijelaskan, mereka cenderung mudah menyerah ketika menghadapi pekerjaan yang tidak dapat dilakukan. Salah satunya dipengaruhi oleh fasilitas dan perkembangan teknologi. Mereka tidak mau/tidak mampu melakukan tugas atau pekerjaannya padahal mereka mampu berjamjam di depan perangkat teknologi, baik handphone (HP) maupun komputer untuk membuka sosial media atau bermain game. Akibatnya, mereka terkena penyakit mental, seperti malas berusaha, mudah putus asa, tidak bertanggung jawab, tidak disiplin, bangga dengan fasilitas mewah, tidak mampu menyelesaikan masalah, menyerah dengan keadaan, dan sebagainya.

\section{Teori Daya Juang}

Daya juang didefinisikan sebagai kemampuan seseorang untuk melakukan tindakan dan upaya melangkah ke depan secara maksimal dan mengatasi segala kesulitan atau rintangan untuk mencapai tujuan tertentu (Oktariningtyas, 2010). Sementara itu, definisi lain menyebutkan bahwa daya juang merupakan kerangka konseptual yang mampu meramalkan seberapa jauh seseorang mampu mengatasi permasalahan-permasalahan/kesulitan-kesulitan dalam kehidupannya (Lestari, 2014). Berdasarkan kedua definisi tersebut, disimpulkan bahwa daya juang merupakan kemampuan seseorang dalam menghadapi permasalahannya secara positif sehingga dapat mengatasinya dan mencapai tujuan yang diharapkan.

Sejalan dengan pengertian di atas, Stoltz Paul G. (dalam Santos, 2012) menyatakan daya juang sebagai Adversity Quotient yaitu kemampuan seseorang dalam merespon dan mengatasi tekanan dan kesulitan-kesulitan yang dihadapinya. Menurutnya, masa depan seseorang dipengaruhi oleh upaya yang dilakukannya hari ini. Terkait dengan ini, Ryan \& Deci (2006) dalam teorinya tentang self determination (penentuan nasib diri) menyebutkan bahwa manusia memiliki dorongan dalam dirinya untuk berjuang, untuk meningkatkan kepribadian dan regulasi dirinya. Selain dorongan dari dalam diri, manusia membutuhkan pengetahuan sebagai motivasi dan pengalaman positif untuk meningkatkan prestasi dan kesejahteraan. Menurut Bandura \& Zimmerman (dalam Astutik, Wismanto, dan Goeritno, 2012) Regulasi diri merupakan kemampuan mengatur tingkah laku untuk meningkatkan performansi diri (berhubungan secara positif dengan prestasi akademis). Selain itu, hubungan sosial yang positif merupakan hal penting yang dibutuhkan dalam meningkatkan regulasi diri seseorang. Sehingga dapat dikatakan bahwa untuk dapat berjalan ke depan (mengatasi semua permasalahan kehidupan) dan meningkatkan performa dirinya, manusia membutuhkan dorongan dari dalam diri dan regulasi diri yang dapat mengatur gerak tingkah laku dan kepribadiannya, daya juang, dan dukungan sosial. Selain itu yang tidak kalah penting adalah tuntunan agama yang dianutnya, yang memberikan arah jalan yang terbaik.

Daya juang sama dengan kemampuan menghadapi permasalahan/kesulitan yang dikenal dengan Adversity Quotient/AQ (Hasanah, 2010). Menurut Stoltz (1997) ada tiga tipe manusia yang berkaitan dengan daya 
juang (AQ) yaitu (i) quiter, seseorang yang mudah menyerah, (ii) camper, seseorang yang mudah puas, dan (iii) climber, seseorang yang terus berusaha mencapai tujuannya atau prestasi. Stoltz (1997) mengelompokkan empat aspek daya juang (CO2RE) yang harus dimiliki seseorang untuk dapat mengatasi permasalahan hidupnya, yaitu (i) Control yaitu kendali diri seseorang, keyakinan dirinya bahwa dia dapat mengatasi permasalahannya, (ii) Origin and Ownership yaitu kemampuan memahami sumber masalah dan kemungkinan yang dilakukan seseorang untuk memperbaiki situasi terlepas apakah itu merupakan tanggungjawabnya atau bukan, (iii) Reach merupakan kemampuan menganalisis dan membatasi masalah, sejauh mana seseorang menganggap kesulitan akan memengaruhi aspek atau kondisi lain dalam kehidupannya, dan (iv) Endurance yang berarti lamanya seseorang menganggap kesulitan atau problemnya akan bertahan. Kemampuan ini dapat ditingkatkan melalui LEAD Sequence dari orangtua.

Ketika mengalami permasalahan, seorang anak atau orang dewasa membutuhkan dukungan dari orang-orang terdekatnya terutama orangtua dan keluarga. Dukungan orangtua sangat dibutuhkan dalam meningkatkan motivasi diri (Wati, 2016). Berkaitan dengan hal itu, Stoltz (dalam Santos, 2012) mengembangkan Listen, Explore, Analyse, and Do something (LEAD sequence), sebagai tindakan yang semestinya dilakukan oleh orangtua/keluarga ketika seorang anak mengalami permasalahan. Berdasarkan teori Stoltz ini dapat dikatakan bahwa aspek Listen (mendengarkan) memiliki makna bahwa orangtua seharusnya 'mendengarkan' (menyimak, memberi perhatian, berempati, memberikan rasa tenang, dan dukungan). Explore (menyelidiki) adalah membimbing anak untuk mengetahui sebab dan asal masalah (apa, siapa, dan bagaimana masalah tersebut bisa muncul). Analyse (menganalisis) ialah bimbingan yang diberikan orangtua untuk menganalisa seberapa jauh masalah ini akan berdampak sehingga anak perlu memiliki kemampuan membatasi masalah. Yang terakhir adalah Do something (melakukan sesuatu) ialah bimbingan yang diberikan untuk melakukan tindakan yang sesuai atau efektif dalam menyelesaikan masalah setelah dilakukan eksplorasi dan analisis. LEAD sequence ini sebaiknya juga dilakukan oleh pendidik (guru) ketika peserta didiknya mengalami masalah.

Meskipun pola asuh orangtua dan guru tidak secara sengaja dilakukan untuk menumbuhkembangkan daya juang, dengan pola pengukuran tertentu dapat dilihat bagaimana pola asuh tersebut berkontribusi terhadap daya juang siswa. Berikut ialah indikator daya juang dan indikator pola asuh yang dapat menumbuhkan daya juang (Tabel 1 ).

Berdasarkan teori tersebut dapat dikatakan bahwa definisi daya juang ialah kemampuan seseorang dalam memecahkan permasalahan hidupnya. Kemampuan ini ditandai dengan adanya kendali diri; kemampuan mengeksplorasi (mengetahui penyebab masalah) "who, what, why, when, where"; kemampuan menganalisis

Tabel 1. Indikator Daya Juang dan Pola Asuh

\begin{tabular}{lll}
\hline Indikator Daya Juang & Indikator Pola Asuh \\
\hline Kendali Diri (Control) & $\begin{array}{l}\text { Mendengarkan (Listen) } \\
\text { Kemampuan mengeksplorasi dan } \\
\text { tanggung jawab (Origin and } \\
\text { Responsibility) }\end{array}$ & $\begin{array}{l}\text { Membimbing untuk mengeksplorasi } \\
\text { (Eksplore) }\end{array}$ \\
Kemampuan Menganalisis dan & $\begin{array}{l}\text { Membimbing untuk menganalisis } \\
\text { membatasi masalah (Reach) }\end{array}$ & $\begin{array}{l}\text { Membis) } \\
\text { Daya tahan (Endurance) }\end{array}$ \\
memecahkan masalah (Do something)
\end{tabular}

Sumber: Santos (2012) 
Nur Listiawati, Persepsi Siswa Terhadap Daya Juang Mereka Serta Pola Asuh Orangtua dan Guru Di SD Berakreditasi A dan C di Kabupaten Bantul dan Bone Bolango

dan membatasi masalah; dan daya tahan. Sedangkan pola asuh yang menumbuhkembangkan daya juang ialah pola asuh yang berdampak pada peningkatan daya juang.

\section{Perkembangan Anak Usia 9-12 Tahun}

Perkembangan manusia merupakan perubahan yang bersifat kualitatif fungsional, berbeda dengan pertumbuhan yang sifatnya kuantitatif. Proses tumbuh kembang dikelompokkan menjadi tiga aspek yaitu biologis (perkembangan pada fisik), kognitif (perubahan kemampuan dan cara berpikir), dan psikososial (perubahan aspek perasaan, emosi, dan hubungan dengan orang lain (Syamsussabri, 2013). Proses tumbuh kembang terjadi secara progresif dan beraturan, serta saling memengaruhi. Demikian juga, perkembangan kepribadian seseorang pada fase terdahulu memengaruhi fase berikutnya. Sedangkan menurut Karini, Herlinawati, dan Moelyo (2009), Chamidah (2009), \& Prastowo (2014) faktor internal dan eksternal seorang individu memengaruhi proses perkembangan kepribadiannya. Dengan demikian, perkembangan seorang individu, baik perkembangan biologis, kognitif, maupun psikososial dipengaruhi oleh faktor di luar dirinya.

Selanjutnya, perkembangan anak dalam hal kepribadiannya terdiri atas aspek kognitif, fisikmotorik, afeksi, bahasa, moral dan keagamaan. Pada aspek kognitif anak usia 6-7 tahun mengawali perkembangannya dengan kemampuan memecahkan masalah sederhana, yang selanjutnya berkembang ke arah pemahaman dan pemecahan masalah yang lebih rumit. Menurut Piaget (dalam Ibda 2015), Mutammam \& Budiarto, (2013) Desstya (2014), perkembangan kognitif terdiri atas periode sensori motorik (usia 0-2 tahun), periode praoperasional (2-7 tahun), periode operasional konkrit (7-11 atau 12 tahun), dan periode operasional formal (11/12 - 14/15 tahun).

Usia 6-11 tahun merupakan tahap industry vs inferiority (Erikson dalam Tatala, 2009; Sokol, 2009). Pada usia ini seorang anak mulai berpikir deduktif dan taat pada peraturan. Pada tahap ini seorang anak mulai mengembangkan sense of industry dimana dia mulai berusaha mengontrol imajinasinya dan mengaplikasikannya pada hal produktif dalam melaksanakan tugas-tugas sekolahnya maupun dalam aktivitas bermainnya. Jika dia berhasil, misalnya memperoleh nilai yang baik atau mendapatkan apresiasi dari orang lain yang menunjukkan 'kompetensinya', maka akan tumbuh rasa menguasai dalam dirinya. Namun, di sisi lain, akan timbul 'inferiority' dalam dirinya. Sementara itu, Eccles (1999) membagi usia 610 tahun sebagai masa kanak-kanak pertengahan dan 11-14 tahun sebagai masa remaja. Perkembangan di kedua periode tersebut dikendalikan dengan kebutuhan psikologis dasar untuk memperoleh kompetensi, autonomi dalam membuat keputusan secara mandiri dan membentuk hubungan sosial yang baik dengan teman sebaya dan orang-orang dewasa di luar lingkungan keluarganya. Tekanan kelompok atau peer group-nya terlihat lebih besar dan anak mulai melepaskan diri dari orangtuanya pada usia 10-12 tahun (Hervira \& Maharani, 2012; Musfirah, 2013). Menurut Witherington, Usia 9-12 tahun memiliki ciri perkembangan sikap individualis sebagai tahap lanjut dari usia 6-9 tahun dengan ciri perkembangan sosial yang pesat (Setiawan, 2015). Pada tahapan ini seorang anak berusaha untuk mengenal siapa dirinya dengan membandingkan dirinya dengan teman sebayanya. Pada proses ini anak membutuhkan bimbingan untuk beradaptasi dengan lingkungannya. Sehingga pada usia 9-12 tahun seorang anak sudah memiliki kepercayaan diri, konsep diri, dan dapat mengenali dan menilai dirinya dan orang lain.

Sesuai dengan perkembangan usianya, anak menghadapi masalah hidupnya. Anak memiliki kemampuan mengatasi masalah secara bertahap, dari yang paling mudah hingga yang sulit sesuai usianya. Perkembangan kognitif, fisik motorik, afeksi, bahasa, moral, dan keagamaan menentukan kemampuan anak mengatasi masalahnya. Namun, perkembangan kognitif sangat memengaruhi seorang anak untuk dapat 
mengeksplorasi dan menganalisa masalah yang dihadapi.

Mengacu pada uraian di atas, rumusan masalah dalam studi ini yaitu 1) bagaimana pola asuh orangtua dan guru di dua lokasi yang berbeda yaitu di Kabupaten Bantul dan Bone Bolango dalam menumbuhkembangkan potensi daya juang siswa; 2) bagaimana persepsi daya juang siswa di kedua lokasi tersebut terhadap potensi daya juang mereka. Penelitian juga mempertimbangkan faktor akreditasi sekolah.

Berdasarkan pada rumusuan masalah, tujuan studi ini dimaksudkan untuk mengkaji 1) pola asuh orang tua dan guru dalam menumbuhkan potensi daya juang siswa; dan 2) persepsi siswa terhadap potensi daya juang mereka.

\section{METODE}

Studi ini merupakan studi kasus yang dilakukan di dua sekolah di Kabupaten Bantul dan dua sekolah di Kabupaten Bone Bolango. Lokasi sampel dipilih dengan pertimbangan bahwa keduanya memiliki ciri berada di lokasi yang tidak jauh dari kota propinsi, satu berada di lokasi rawan bencana dan satu berada di lokasi yang aman namun ditengarai bahwa wanita daerah Gorontalo memiliki daya juang yang tinggi yang ditandai dengan sedikitnya ada 73 kepala desa perempuan se-gorontalo (Robin, 2016). Sekolah yang dipilih adalah yang berakreditasi $A$ dan $C$ pada masing-masing lokasi untuk melihat bagaimana daya juang siswa pada sekolah- sekolah tersebut. Berdasarkan keterbatasan sampel yang ada, maka hasil yang diperoleh merupakan kesimpulan untuk sekolah sampel saja. Tabel 2 merupakan sumber data yang menjadi target dalam studi.

Responden merupakan siswa kelas IV-VI berusia 9-12 tahun. Studi dibatasi pada pengukuran daya juang siswa menurut persepsi responden siswa itu sendiri dan pola asuh orangtua dan guru berdasarkan persepsi siswa. Instrumen pengukuran daya juang siswa menggunakan metode self inventory dengan format children friendly.

Pemilihan metode tes ini bertujuan untuk mengukur minat, perilaku, atau kepribadian. Siswa diminta memilih salah satu dari dua pilihan yang berisi contoh perilaku anak lain yang sebaya yang dihadapkan pada situasi tertentu. Situasi merupakan kondisi familiar yang biasa dihadapi anak sehari-hari. Salah satu contoh perilaku berisi aspek daya juang sedangkan yang lainnya bukan merupakan aspek daya juang. Domain yang diukur mencakup sikap, akademis, dan keterampilan. Instrumen berisi 30 pertanyaan. Realibilitas instrumen berdasarkan Nilai Cronbach Alpha mencapai > 0.6 yang menunjukkan instrumen reliabel (George \& Mallery, 2003), pada pengukuran daya juang tiap butir instrumen $>0.6$ sehingga 100 persen reliable. Sedangkan validitas nilai corrected item-total correlation $>0.3$ yang menunjukkan $70 \%$ item valid (Azwar, 2000).

Tabel 2. Sumber Data

\begin{tabular}{llllll}
\hline \multirow{2}{*}{ Kab/Kota } & Akreditasi & & & & Total \\
& & Kelas 4 & Kelas 5 & Kelas 6 & \\
\hline Kab. Bantul & A & 0 & 25 & 26 & 51 \\
& C & 16 & 16 & 19 & 51 \\
\cline { 1 - 5 } Kab. Bone Bolango & C & 17 & 12 & 11 & 40 \\
& A & 0 & 27 & 26 & 53 \\
\hline Total & & 33 & 80 & 82 & 195 \\
\hline
\end{tabular}

Sumber: hasil olah data peneliti 


\section{HASIL DAN PEMBAHASAN}

Pola Asuh Orangtua dalam Menumbuhkan Daya Juang

Pola asuh orangtua dan guru diukur berdasarkan empat aspek yang dapat menumbuhkan daya juang siswa, yaitu tindakan yang dilakukan orangtua dan guru saat anak mengalami masalah, yaitu 1) mendengarkan penjelasan anak tentang permasalahan yang dialaminya sehingga anak yakin bisa mengatasi masalahnya dan memiliki kontrol diri yang baik; 2) membimbing untuk melakukan eksplorasi terhadap permasalahan yang dialami sehingga anak memahami sumber permasalahannya; 3) membimbing untuk menganalisa permasalahan yang dialami, memahami efek yang dapat ditimbulkan sehingga harus diatasi dengan segera, dan tidak memengaruhi sisi kehidupan lainnya; dan 4) membimbing siswa untuk melakukan sesuatu dalam mengatasi masalahnya sehingga tumbuh semangat, motivasi dan pemahaman bahwa masalah tidak akan bertahan lama karena mampu diatasi segera. Pola asuh ini sesuai dengan potensi daya juang yang ditumbuhkan pada anak yang mengacu pada teori Adversity Quotient ( $A Q$ ). Pola asuh orangtua atau guru diukur dengan cara siswa memilih apakah perilaku yang dijabarkan merupakan tindakan orangtua atau guru yang biasa mereka lihat dan temui. Domain yang diukur mencakup kognitif, afeksi, dan psikomotorik.

\section{Persepsi Siswa tentang Pola Asuh Orangtua di Kabupaten Bantul}

Hasil penelitian mengungkapkan bahwa pola asuh orangtua di sekolah sampel terakreditasi A secara umum lebih baik dalam menumbuhkan aspek-aspek daya juang pada siswa dibandingkan sekolah terakreditasi C. Aspek mendengarkan apa yang disampaikan siswa kepada orangtuanya memiliki skor lebih tinggi dibandingkan aspek lainnya (skor tertinggi adalah 6). Aspek analisa memiliki skor paling rendah dari aspek lainnya. Menganalisa merupakan kemampuan seseorang untuk melihat seberapa jauh suatu masalah akan memiliki jangkauan atau dampak pada sisi kehidupannya. Dengan menganalisa maka seseorang diharapkan juga bisa membatasi agar masalah yang dihadapinya tidak menjangkau sisi lain kehidupannya (tidak melebar) dan diatasi dengan baik. Jika di dilihat secara umum dalam satu kelompok pola asuh orangtua di kedua sekolah, dengan median 5.25 dan standar deviasi 0.18. maka dapat dilihat berdasarkan skala kelompok, dengan batas atas 5.41 dan batas bawah 5.06, aspek mendengarkan (listen), membimbing siswa untuk mengeksplorasi (eksplore), dan melakukan sesuatu (do something) berada pada posisi skor sedang, sedangkan pola asuh orangtua membimbing siswa menganalisis (analyse) berada pada kelompok skor rendah, seperti terlihat pada Grafik 1.

Rendahnya kemampuan orangtua dalam memberikan bimbingan untuk menganalisis masalah dapat disebabkan karena latar belakang pendidikannya. Namun demikian, peneliti tidak

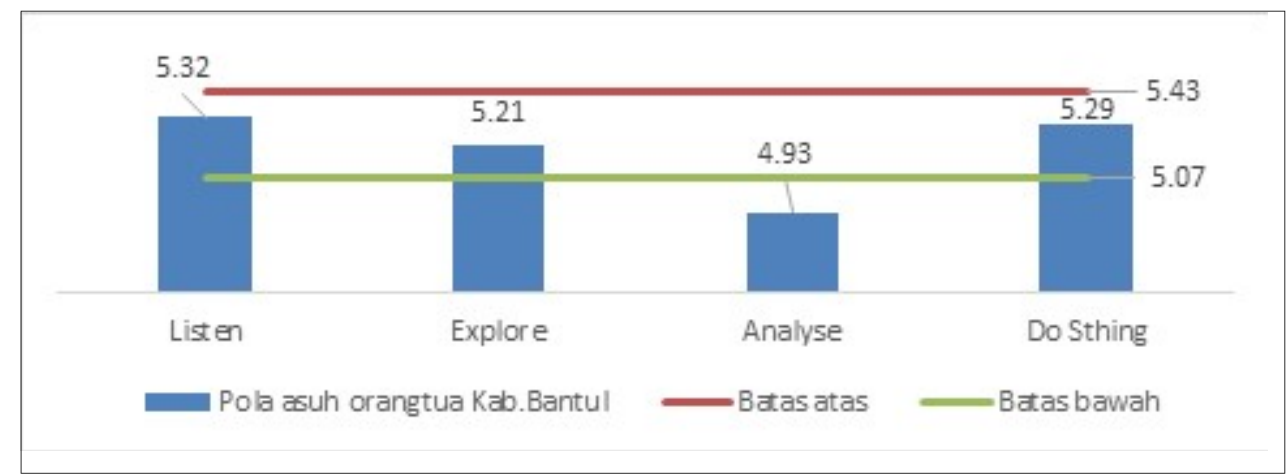

Grafik 1. Pola Asuh Orangtua di SD Sampel Kabupaten Bantul Berdasarkan Skor Kelompok 


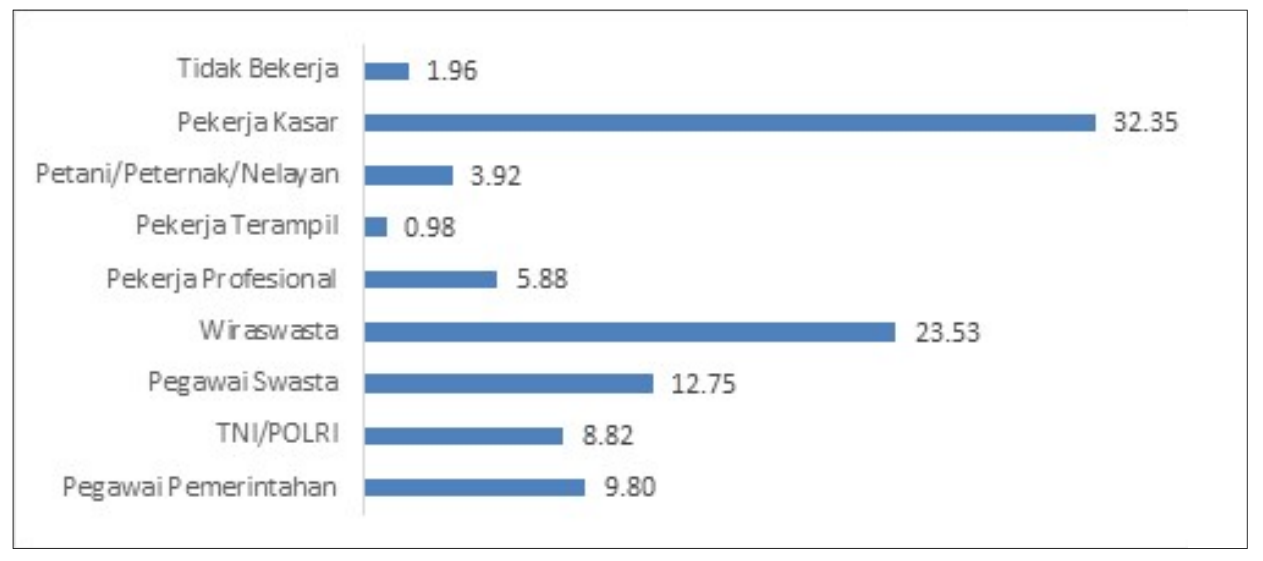

Grafik 2. Pekerjaan Orangtua Siswa di SD Sampel Kabupaten Bantul

mengkaji latar belakang pendidikan orangtua dengan pertimbangan tidak semua siswa memahami latar belakang pendidikan orangtuanya, akan tetapi siswa memahami pekerjaan orangtua mereka. Berdasarkan pekerjaan ayah yang dikaji dalam penelitian ini terlihat bahwa persentase ayah bekerja sebagai pekerja kasar dan wiraswasta (dalam skala kecil) mendominasi kelompok pekerjaan orangtua. Hal tersebut mendominasi hasil pola asuh orangtua yang menunjukkan bahwa bimbingan orangtua untuk menganalisa masalah yang dihadapi siswa juga rendah. Hasil penelitian Sandstrom \& Huerta (2013) menunjukkan bahwa perkembangan kognitif anak sangat sensitif terhadap pendapatan keluarga yang rendah (low family income). Demikian juga hasil penelitian Patenaude (2015) menyatakan anak-anak yang tinggal dalam rumah tangga berpenghasilan rendah yang bertahan dalam ketidakstabilan keluarga dan pengasuhan yang emosional memiliki resiko terganggu kemampuan kogni-

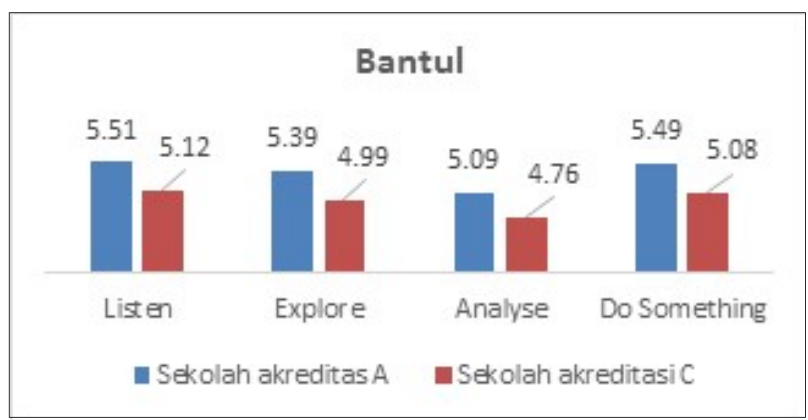

Grafik 3a. dan b Pola Asuh Orangtua Siswa di SD Sampel di Kabupaten Bantul dan Bone Bolango tifnya, ini juga didukung oleh penelitian Willingham (2012). Ketiga penelitian tersebut menyatakan bahwa pendapatan orangtua yang rendah memberikan efek negatif pada perkembangan kognitif anak. Pengasuhan yang emosional juga dapat disebabkan oleh pendapatan keluarga yang rendah. Sementara aspek kognitif dan pengasuhan yang emosional memengaruhi kemampuan anak untuk menganalisa.

Sementara itu, jika dilihat dari status pekerjaan orangtua siswa, $57.8 \%$ orangtua siswa kedua-duanya bekerja. Sebanyak $40.20 \%$ ibu dari siswa tidak bekerja dan 1,96\% ayah siswa tidak bekerja. Namun, berdasarkan uji perbedaan status jenis pekerjaan orangtua maupun status orangtua bekerja atau tidak, tidak memberikan pengaruh yang signifikan terhadap daya juang siswa. Hal ini berbeda dengan hasil penelitian Sandstrom \& Huerta (2013) yang menunjukkan bahwa pekerjaan orangtua dengan pendapatan rendah dan

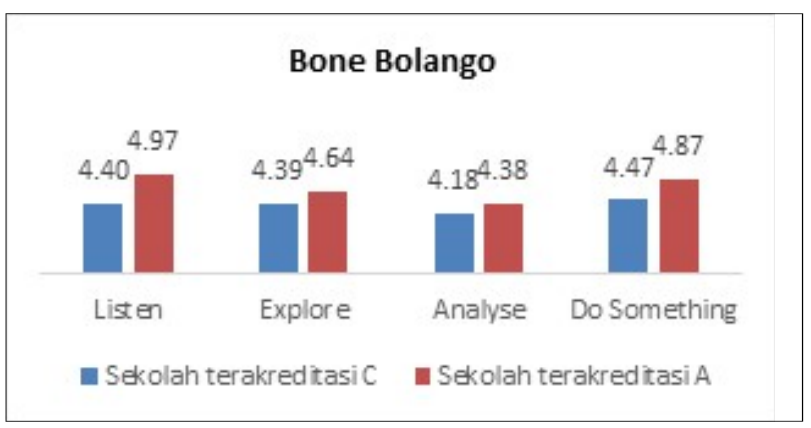


kondisi ekonomi orangtua yang tidak stabil secara negatif memengaruhi kondisi sosial emosional, kemampuan kognitif, dan prestasi akademik siswa yang berarti juga memengaruhi daya juangnya.

\section{Persepsi Siswa tentang Pola Asuh Orangtua di Kabupaten Bone Bolango}

Pola asuh orangtua SD sampel yang berada di Kabupaten Bone Bolango menunjukkan pola yang hampir sama dengan pola asuh orangtua di Kabupaten Bantul, di mana pola asuh orangtua yang siswanya bersekolah di SD yang berakreditasi A lebih baik dari pada pola asuh orangtua yang siswanya berada di SD terakreditasi C. Demikian juga aspek terendah, ada pada pola asuh orangtua dalam menganalisa permasalahan. Kesamaan pola dalam pola asuh ini dapat disebabkan kesamaan faktor yang memengaruhinya.
Untuk melihat batasan tinggi rendahnya skor maka perlu mengelompokkan skor berdasarkan kelompok. Dengan median 4.71 dan standar deviasi 0.13 diperoleh batas atas 4.84 dan batas bawah 4.58 untuk mengelompokkan nilai tinggi, sedang, dan rendah. Terlihat bahwa pola asuh orangtua siswa dalam membimbing siswa menganalisa di sekolah sampel yang berada di Kabupaten Bone Bolango berada pada kelompok skor rendah. Sementara pola asuh orangtua pada tiga aspek lainnya berada dalam kelompok skor sedang (perhatikan Gambar 4).

Jika dilihat dari pekerjaan orangtua yang sudah dikelompokkan ke dalam jenis kelompok pekerjaan tertentu, terlihat bahwa data jenis pekerjaan orangtua di Kabupaten Bantul dan Bone Bolango memiliki pola yang sama, di mana jenis pekerjaan sebagai pekerja kasar menempati persentase yang paling besar, sementara orangtua berwiraswasta menempati posisi kedua terbanyak. Kelompok wiraswasta

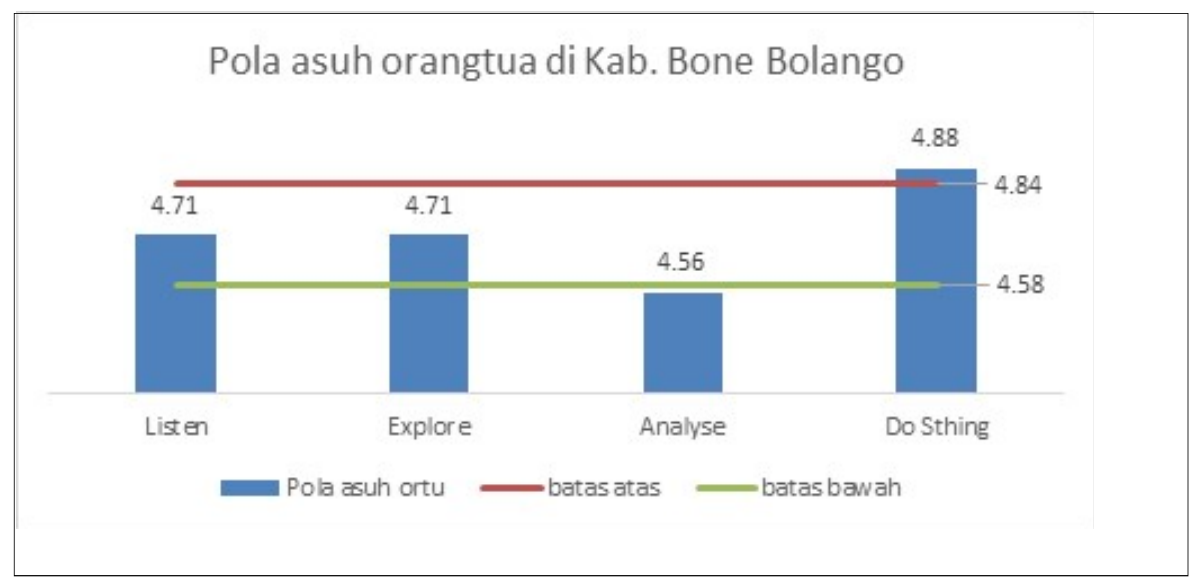

Grafik 4. Pola Asuh Orangtua Siswa di SD Sampel di Kabupaten Bone Bolango Berdasarkan Skor Kelompok

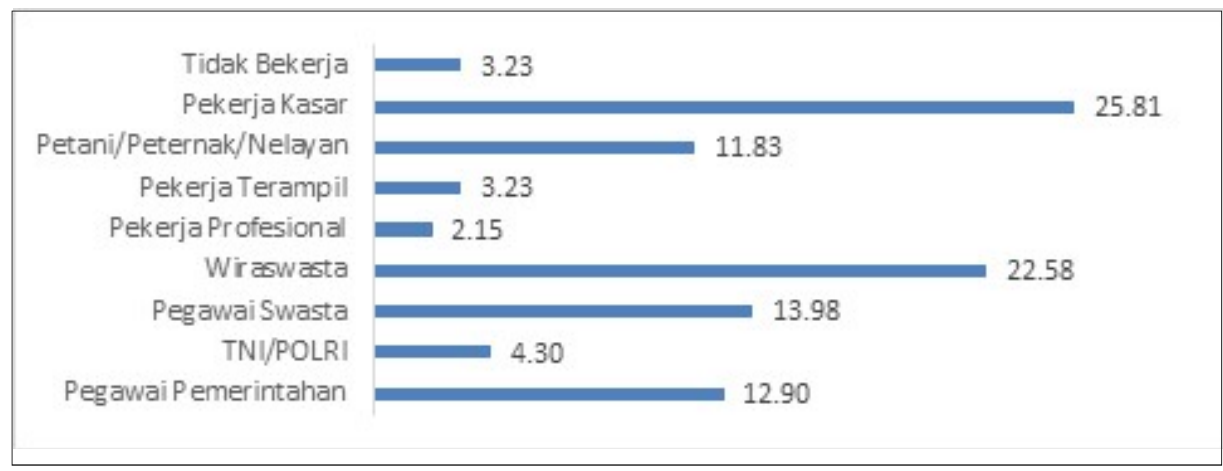

Grafik 5. Pekerjaan Orangtua Siswa di Sekolah Sampel Kabupaten Bone Bolango 
ini sebagian besar adalah pada tingkatan menengah ke bawah. Hal ini berpengaruh pada kemampuan orangtua dalam memberikan bimbingan untuk menganalisis permasalahan yang dialami siswa. Ini diperkuat (Eccles \& Kean, 2005) yang menyatakan bahwa kenyamanan tempat tinggal, pendapatan yang rendah, dan pekerjaan yang penuh tekanan dapat memengaruhi kesehatan mental orangtua sehingga membuat mereka sulit untuk memberikan pengalaman yang mengandung stimulasi kognitif bagi anak-anaknya. Tekanan ini juga menurunkan kemampuan orangtua memberikan kehangatan, lingkungan yang mendukung dan konsisten bagi anak sehingga menghambat anak untuk menikmati kesempatan belajar penuh di sekolah. Sehingga kemampuan memberikan stimulasi kognitif oleh orangtua juga dipengaruhi oleh kesehatan mental yang secara tidak langsung juga dipengaruhi oleh kondisi sosial ekonomi keluarga.

Berdasarkan pola asuh orangtua di Kabupaten Bantul dan Bone Bolango (Grafik 3). Terlihat bahwa pola asuh orangtua di sekolah sampel di Kabupaten Bantul lebih tinggi dari pada pola asuh orangtua di sekolah sampel Kabupaten Bone Bolango, dengan range perbandingan 0,61 - 0.67. Dengan nilai tertinggi 6 , perbedaan ini cukup bermakna, sehingga dapat dikatakan bahwa ada nilai plus dalam pola asuh orangtua siswa di Kabupaten Bantul dibandingkan orangtua di Kabupaten Bone Bolango. Ini didukung oleh penelitian Hafstad, Haavind, \& Jensen (2011) bahwa pengasuhan orangtua yang daerahnya merupakan lokasi rawan bencana, seperti Kabupaten Bantul, mem- perlihatkan kecenderungan bahwa kesadaran mereka meningkat terhadap: 1) reaksi yang diberikan anaknya; 2) kemampuan observasi terhadap kondisi anak (memahami akan tandatanda yang diperlihatkan); 3) perhatian melalui tindakan monitoring; dan 4) kemampuan menginterpretasi perubahan tingkah laku anak. Dengan demikian, kesadaran dan kemampuan observasi orangtua terhadap kondisi anak di daerah yang rawan bencana lebih tinggi daripada di daerah bukan lokasi rawan bencana seperti Kabupaten Bone Bolango. Orangtua di lokasi rawan bencana lebih mampu melihat tanda-tanda jika anak mengalami masalah dan memiliki strategi untuk mencegah dan mengurangi masalah, serta memulihkan kondisi aman dan nyaman pada anak melalui bimbingan. Sementara penelitian Wiharsih (2006) menyatakan bahwa bencana (gempa) tidak membuat orangtua menyerah untuk menyekolahkan anak mereka. Mereka memiliki semangat yang tinggi untuk masa depan anakanak mereka. Tekanan kondisi sosial termasuk bencana, memotivasi seseorang untuk melakukan kegiatan dengan lebih baik dan teratur. Hal ini berdampak pada ketangguhan (resilience) anak untuk mampu menanggulangi kesulitan hidupnya.

Perilaku siswa tidak hanya dipengaruhi oleh pola asuh orangtua di rumah tetapi juga pola asuh guru di sekolah karena siswa berada di sekolah selama $\geq 5$ jam dalam 5 hari atau 6 hari dalam seminggu (Senin-Jumat atau SeninSabtu). Pengasuhan oleh guru dalam menumbuhkembangkan daya juang siswa diukur dengan cara yang sama dengan pengasuhan orang tua.

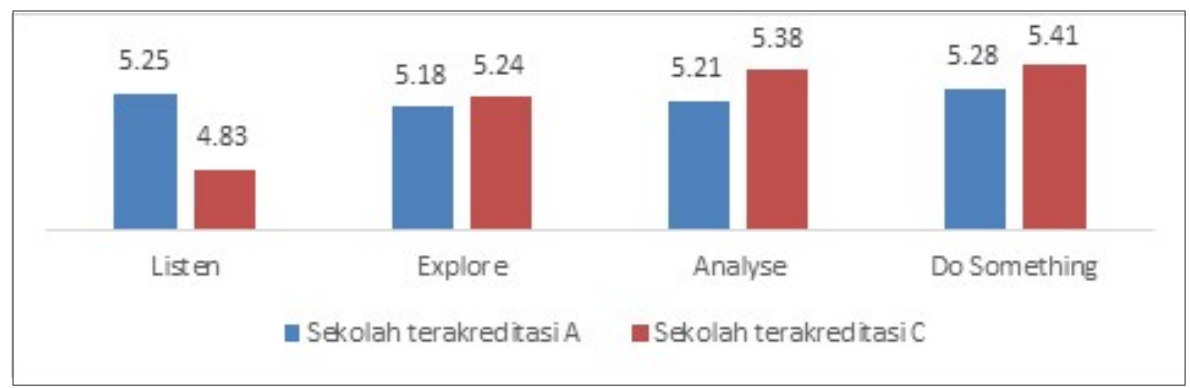

Grafik 6. Pola Asuh Guru di SD Sampel Kabupaten Bantul 
Terkait dengan penumbuhkembangan daya juang, dipaparkan pula bagaimana pola asuh guru di dua lokasi penelitian ini.

\section{Persepsi Siswa tentang Pola Asuh Guru di Sekolah Sampel Kabupaten Bantul}

Berbeda dengan pola asuh orangtua, pola asuh guru yang diukur dengan cara yang sama dengan pola asuh orangtua yaitu berdasarkan aspek mendengarkan, mengeksplorasi, menganalisa dan melakukan sesuatu memperlihatkan hasil yang berbeda, dimana aspek mendengarkan pada guru merupakan aspek terendah dari semua aspek di dua sekolah sampel tersebut. Kompetensi mendengarkan guru di sekolah terakreditasi $\mathrm{C}$ jauh lebih rendah dari pada sekolah yang terakreditasi $A$.

Hasil ini menunjukkan bahwa guru di sekolah sampel terakreditasi $\mathrm{C}$ memiliki skor lebih rendah dalam kompetensi mendengarkan apa yang disampaikan siswanya dibanding guru di sekolah berakreditasi A. Listen atau mendengarkan memiliki pengertian luas yaitu memberikan perhatian, menyimak, peduli, menghargai, dan memberikan perasaan tenang serta nyaman.
Sementara pada sisi siswa, jika mereka 'didengar' maka akan menumbuhkan rasa dihargai, merasa mendapatkan dukungan, menumbuhkan ketenangan dan percaya diri. Sementara kompetensi mendengarkan pada guru sekolah terakreditasi A skornya cukup tinggi. Demikian juga dengan kemampuan memberikan bimbingan untuk mengeksplorasi, menganalisa, dan membimbing untuk melakukan tindakan skornya tinggi (di atas 5, dengan skor maksimum 6). Kemampuan 'mendengarkan' guru di sekolah terakreditasi A terlihat dalam observasi, di mana ada hubungan yang sangat akrab antara guru dan siswa. Hubungan ini menandakan adanya perasaan dihargai pada diri siswa oleh guru mereka. Hal ini juga menandakan bahwa guru 'mendengarkan' siswanya sehingga secara kasat mata terlihat bahwa siswa di sekolah berakreditasi A lebih ceria dan semangat dibandingkan siswa di sekolah terakreditasi $\mathrm{C}$.

Dalam skala kelompok untuk kedua sekolah tersebut, dengan median 5.25 dan standar deviasi 0.13 , aspek-aspek penumbuhan daya juang oleh guru di dua sekolah sampel ini skornya berada pada kelompok rendah hingga sedang.

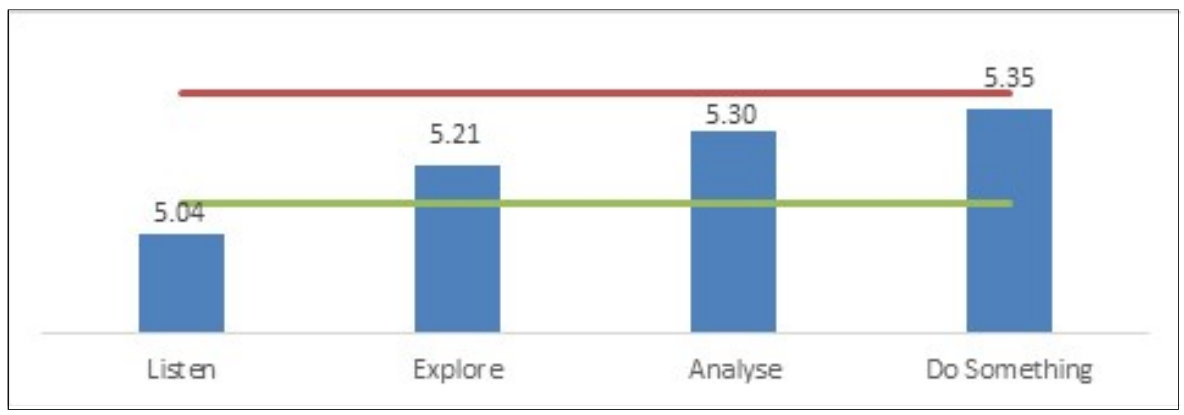

Grafik 7. Pola Asuh Guru di SD Sampel Kabupaten Bantul Berdasarkan Skor kelompok

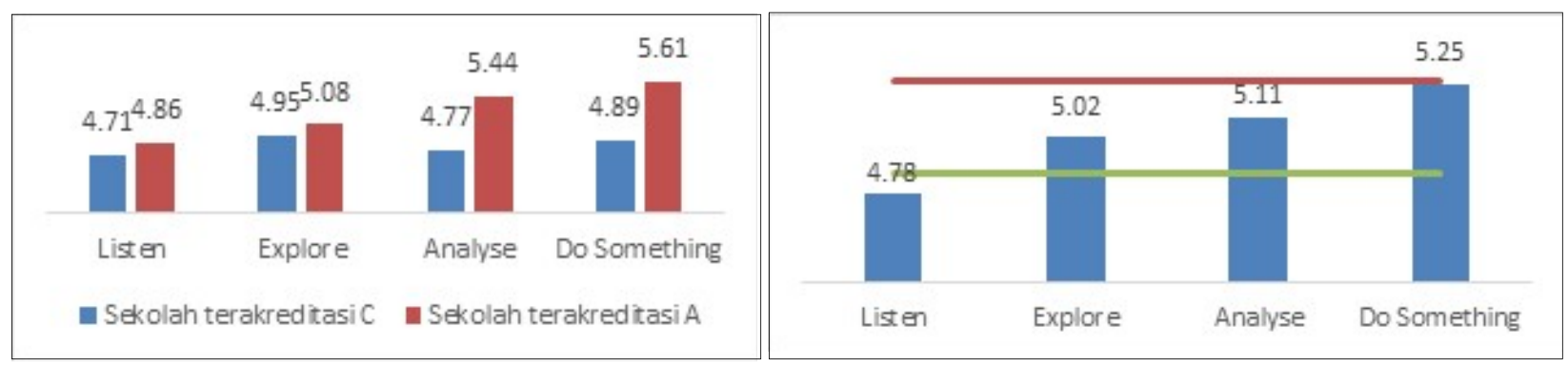

Grafik 8 a. Pola Asuh Guru di SD Sampel Kabupaten Bone Bolango; Grafik 8b. Pola Asuh Guru Berdasarkan Standar Kelompok di SD Sampel Kabupaten Bone Bolango 


\section{Persepsi Siswa tentang Pola Asuh Guru di Sekolah Sampel Kabupaten Bone Bolango}

Pola asuh terkait penumbuhan daya juang yang dilakukan guru di dua sekolah sampel Kabupaten Bone Bolango berdasarkan persepsi responden siswa dapat dilihat pada Grafik 8. Terlihat bahwa pola asuh guru di sekolah sampel terakreditasi C pada keempat aspek daya juang lebih rendah daripada sekolah yang terakreditasi A. Pada sekolah yang terakreditasi $C$ kemampuan guru dalam membimbing siswa untuk mengetahui sumber masalah yang dialami siswa serta penyebabnya memiliki skor lebih tinggi dari aspek lainnya. Sementara di sekolah terakreditasi A aspek membimbing siswa untuk melakukan sesuatu skornya lebih tinggi dari aspek lainnya. Sementara, kemampuan guru di kedua sekolah tersebut untuk 'mendengarkan' lebih rendah dari aspek lainnya, walaupun masih dalam skor sedang.

Pada sekolah terakreditasi A skor guru dalam mendengarkan dan menyimak, serta membimbing siswa untuk mengetahui akar permasalahan dan membatasi permasalahan lebih rendah dari membimbing siswa untuk bertindak. Sementara guru lebih banyak memberikan instruksi untuk bertindak menyelesaikan masalah. Salah satu contoh pertanyaan yang menunjukkan persepsi siswa tentang kemampuan mendengarkan guru ialah siswa menjawab tidak pada pernyataan "saya selalu bercerita kepada guru tentang masalah yang saya alami". Jika siswa tidak bercerita kepada guru tentang masalahnya, kemungkinan siswa menganggap guru tidak "mendengarkan" atau memberi solusi kepada permasalahan yang dihadapinya atau siswa takut menceritakan kepada guru karena merasa tidak nyaman, guru terlalu sibuk dengan pekerjaannya, atau ada faktor lainnya.

Pada skala kelompok untuk kedua sekolah tersebut, dengan median 5.06 dan standar deviasi 0.20 terlibat bahwa kemampuan guru dalam menumbuhkan daya juang siswa cenderung tidak normatif, guru kurang dalam 'mendengarkan' sementara lebih banyak melakukan instruksi untuk bertindak. Demikian juga, dengan pola asuh guru di sekolah tersebut dimana aspek mendengarkan seharusnya lebih tinggi dari aspek lainnya, disusul dengan membimbing siswa untuk mengeksplorasi, menganalisis, baru kemudian melakukan suatu tindakan. Dapat disimpulkan bahwa pola asuh guru di kedua lokasi penelitian memiliki pola yang sama sehingga kemampuan guru dalam memberikan perhatian, menyimak, menunjukkan kepedulian, memberikan ketenangan dan menghargai siswa masih dalam kelompok skor rendah.

Skor aspek 'mendengarkan' (listen) pada guru di Kabupaten Bantul dan Bone Bolango umumnya cenderung lebih rendah dari aspek lainnya. Skor yang lebih rendah ini dapat disebabkan karena konsentrasi guru yang terbagi antara tugas administratif, beban kurikulum, dan besarnya jumlah siswa di dalam kelas. Aspek 'mendengarkan' ini juga memengaruhi empati guru terhadap siswa. Kondisi tersebut didukung oleh pendapat Cooper (dalam Mausethagen, 2013) yang menyatakan meskipun keinginan guru untuk mendukung, merawat dan meningkatkan hubungan dengan siswa tinggi, tetapi hal ini dibatasi oleh kondisi kerja mereka.

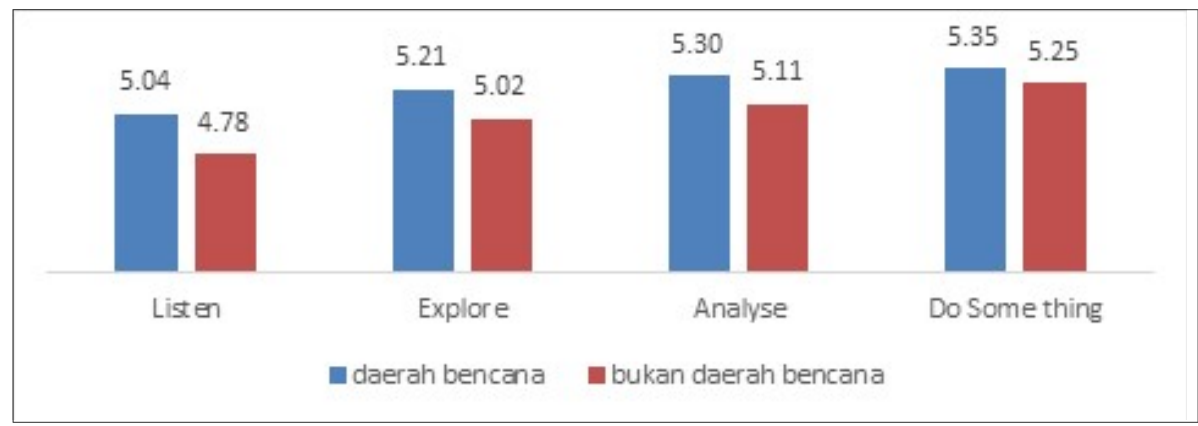

Grafik 9. Pola Asuh Guru SD Sampel di Kabupaten Bantul dan Bone Bolango 
Waktu menjadi terbatas di dalam sistem pendidikan yang berlaku, kurikulum yang kaku, birokrasi, dan besarnya jumlah murid. Kondisi kerja yang tidak mendukung ini menurunkan kompetensi guru untuk 'mendengarkan' permasalahan yang dialami siswa.

\section{Pola Asuh Guru di Sekolah Sampel Kabupaten Bantul dan Bone Bolango}

Terlihat bahwa pola asuh guru di sekolah sampel di Kabupaten Bantul skornya lebih tinggi daripada pola asuh guru di Kabupaten Bone Bolango pada keempat aspek penumbuhan daya juang. Skor terendah pada kedua lokasi ialah pada kemampuan guru untuk mendengarkan.

Dengan aspek yang sama maka dapat dilihat perbedaan skor persepsi siswa terhadap pola asuh guru dan orangtua di kedua lokasi penelitian, seperti pada Grafik 10.

Terlihat bahwa pola asuh guru di kedua lokasi penelitian dalam empat aspek penumbuhkembangan daya juang skornya lebih tinggi dibandingkan dengan pola asuh orangtua. Sementara itu, pola asuh orangtua di Kabupaten Bantul skornya lebih tinggi dibandingkan pola asuh orangtua di Kabupaten Bone Bolango, demikian juga dengan pola asuh guru.

Dengan data dan fakta yang diperoleh dalam kajian maka dapat dikatakan bahwa aspek kognitif memengaruhi kemampuan pola asuh, terutama untuk kemampuan memberikan bimbingan dalam mengeksplorasi dan menganalisis, serta melakukan tindakan untuk menumbuhkembangkan daya juang. Sementara itu, jika dilihat dari pola asuh orangtua dalam menumbuhkan daya juang pada siswa di sekolah sampel Kabupaten Bantul, dengan koefisien determinasi ( $R$ Square), kontribusi seluruh independen variabel (pola asuh orangtua dan guru) secara bersama-sama terhadap daya juang sebesar 30,9 persen, sisanya dipengaruhi oleh variabel lain yang tidak diteliti.

Berdasarkan uji perbedaan (secara statistik), pola asuh guru dalam keempat aspek daya juang, secara parsial tidak memberikan pengaruh signifikan pada daya juang siswa. Dengan kata lain pengasuhan guru dalam menumbuhkembangkan daya juang siswa tidak memberikan pengaruh berarti jika dilakukan tanpa pengasuhan orangtua. Sementara pola asuh orangtua memberikan pengaruh signifikan (0.02, sig. jika $<0.05)$ untuk meningkatkan daya juang siswa terutama dalam membimbing siswa untuk mengeksplorasi dan menganalisis. Pembimbingan orangtua dalam mengeksplorasi dan menganalisis masalah harus lebih ditingkatkan agar daya juang siswa lebih meningkat. Dengan demikian, pola asuh guru tidak akan bermakna dalam menumbuhkembangkan daya juang siswa tanpa pola asuh orangtua.

Hasil uji statistik terhadap pola asuh orangtua dan guru terhadap daya juang siswa sekolah sampel di Kabupaten Bone Bolango menunjukkan bahwa pola asuh mereka secara bersama-sama memberikan kontribusi sebesar
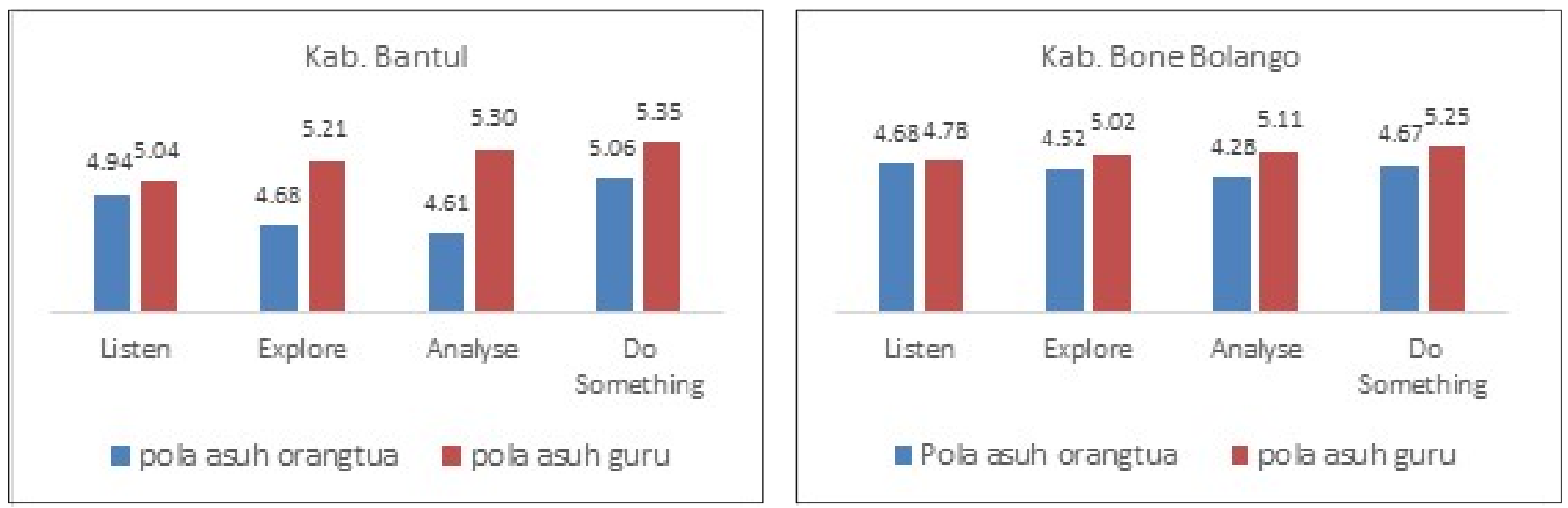

Grafik 10 a dan b Gambaran Pola Asuh Orangtua dan Guru di Kedua Lokasi Penelitian 
32.10 persen ( $R$ Square 0,321) terhadap daya juang siswa. Sementara secara parsial atau sendiri-sendiri, pengaruh pola asuh orangtua secara statistik tidak ada yang signifikan dalam menumbuhkan daya juang siswa (sig. jika $<0.05)$. Pola asuh guru secara parsial berpengaruh pada penumbuhan potensi daya juang siswa hanya pada aspek membimbing siswa untuk bertindak (do something $=0.009$ ) menyelesaikan permasalahan. Sehingga untuk meningkatkan daya juang siswa maka yang perlu diperhatikan dan ditingkatkan adalah aspek membimbing siswa untuk bertindak mengatasi masalahnya. Di sini juga terlihat bahwa pola asuh orangtua saja tidak memberikan makna pada peningkatan daya juang siswa tanpa pola asuh guru. Dengan demikian perlu adanya partnership antara sekolah dan keluarga. Seperti yang dikatakan oleh Rafiq, dkk. (2013), kerja sama ini dapat memperbaiki programprogram sekolah dan iklim sekolah. Sekolah juga dapat memberikan layanan keluarga, mendukung dan meningkatkan kemampuan dan kepemimpinan orangtua, menjembatani orangtua dengan pihak lain di sekolah dan masyarakat. Kerja sama ini juga dapat membantu guru dengan tugas-tugasnya.

\section{Persepsi Siswa tentang Daya Juang Mereka}

Pola asuh orangtua dan guru dalam menumbuhkembangkan daya juang siswa digali melalui persepsi siswa tentang pola asuh yang dilakukan orangtua dan guru. Sementara daya juang siswa juga diukur berdasarkan persepsi siswa sendiri tentang daya juangnya. Pengukuran dilakukan dengan memberikan situasi tertentu pada siswa dan memberikan contoh tindakan yang dilakukan oleh dua orang siswa yang mengalami situasi tersebut. Siswa diminta untuk memilih salah satu tindakan yang lebih mirip dengan tindakan yang dilakukannya jika dia dihadapkan pada situasi tersebut. Siswa diminta memilih bukan yang seharusnya tetapi yang senyatanya dilakukan. Tujuannya ialah mengukur minat, perilaku, dan kepribadian siswa. Pengukuran menggunakan metode self inventory yang merupakan tes psikologi berbentuk self report yang sering digunakan untuk penilaian kepribadian yang menggambarkan kualitas atau karakteristik subjek. Kekuatan dari jenis tes ini ialah lebih reliabel dan valid dari pada tes projektif yang mengukur sisi bawah sadar seperti emosi yang tersembunyi dan konflik internal (Cherry, 2016). Dalam psikologi kepribadian bertanya tentang seperti apa mereka atau bagaimana mereka berperilaku merupakan metode yang paling banyak dipilih. Menurut Vazire (dalam Dodorico, 2008) 98\% studi menggunakan pengukuran jenis ini untuk mengukur kepribadian.

\section{Daya Juang Siswa di Sekolah Sampel Kabupaten Bantul}

Pada Grafik 11 diperlihatkan bahwa skor aspekaspek daya juang yang dimiliki siswa di sekolah terakreditasi A pada umumnya lebih baik daripada siswa di sekolah terakreditasi C (walaupun skor kedua kelompok siswa ini baik, yaitu di atas 5), kecuali pada aspek ke-

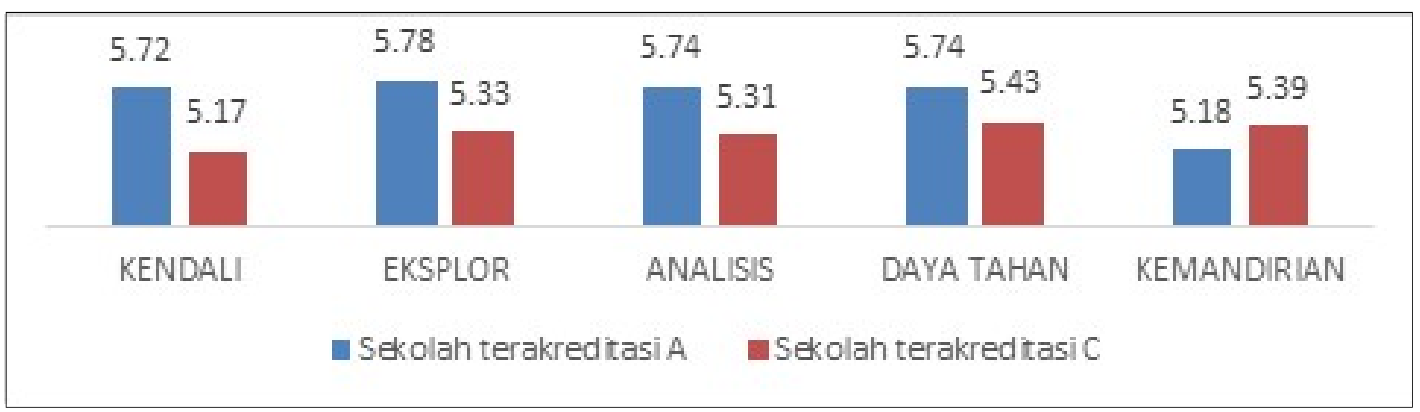

Grafik 11. Daya Juang Siswa di Sekolah Sampel Kabupaten Bantul 
Nur Listiawati, Persepsi Siswa Terhadap Daya Juang Mereka Serta Pola Asuh Orangtua dan Guru Di SD Berakreditasi A dan C di Kabupaten Bantul dan

Tabel 3. Pekerjaan Ayah Siswa di Sekolah Sampel Kabupaten Bantul sekolah terakreditasi A sekolah terakreditasi C

\begin{tabular}{lrr}
\hline Pegawai Pemerintahan & 21.57 & 0 \\
TNI/POLRI & 17.65 & 0 \\
Pegawai Swasta & 13.73 & 9.80 \\
Wiraswasta & 27.45 & 17.65 \\
Pekerja Profesional & 7.84 & 3.92 \\
Pekerja Terampil & 3.92 & 3.92 \\
Petani/Peternak/Nelayan & 1.96 & 5.88 \\
Pekerja Kasar & 5.88 & 56.86 \\
Tidak Bekerja & 0.00 & 1.96 \\
\hline
\end{tabular}

Sumber: hasil olah data peneliti

mandirian, dimana kemandirian siswa sekolah terakreditasi $C$ lebih baik daripada siswa di sekolah terakreditasi $A$.

Pola asuh orangtua siswa dipengaruhi oleh latar belakang pendidikannya. Pada sekolah terakreditasi A, ayah siswa yang menjadi responden sebagian besar memiliki pekerjaan yang mapan sebagai pegawai pemerintahan, TNI/POLRI, pegawai swasta dan wiraswasta. Sementara itu, di sekolah berakreditasi C sebagian besar ayah siswa adalah pekerja kasar (lebih dari 50 persen), seperti terlihat pada Tabel 2.

Pada umumnya, pola asuh anak lebih banyak bergantung pada ibu daripada ayahnya. Ibu siswa sampel yang bersekolah di sekolah terakreditasi $C$ di daerah bencana 49.02 persen bekerja, 13.73 persen diantaranya adalah pekerja kasar/buruh. Adapun 50.98 persen tidak bekerja. Adapun ibu siswa di sekolah terakreditasi A 66.67 persen bekerja (tidak ada yang bekerja sebagai pekerja kasar), dan 33.33 persen tidak bekerja. Sears, dkk. (dalam Catherine Raeff, 2006) menyatakan bahwa ibu pekerja tidak menyukai ketidakmandirian. Selain itu, ibu yang bekerja lebih menginginkan anakanak mereka mematuhi peraturan dari pada orangtua pada masyarakat kelas menengah. Pendapat ini bertentangan dengan hasil yang dicapai siswa dalam kemandiriannya, dimana kemandirian siswa pada sekolah terakreditasi $C$ lebih tinggi daripada kemandirian siswa pada sekolah terakreditasi A, dimana 49.02 ibu siswa sekolah terakreditasi $C$ tidak bekerja, dan ibu siswa pada sekolah terakreditasi A yang tidak bekerja hanya 33.33 persen. Di sini ada faktor lain yang memengaruhi tingkat kemandirian siswa pada keluarga menengah ke atas yang lebih rendah dari kemandirian siswa di sekolah terakreditasi C (sebagian besar ibu dan ayah siswa pada sekolah terakreditasi A memiliki pekerjaan yang mapan). Faktor yang memengaruhi antara lain: ketersediaan fasilitas dan materi pada siswa dengan orangtua yang

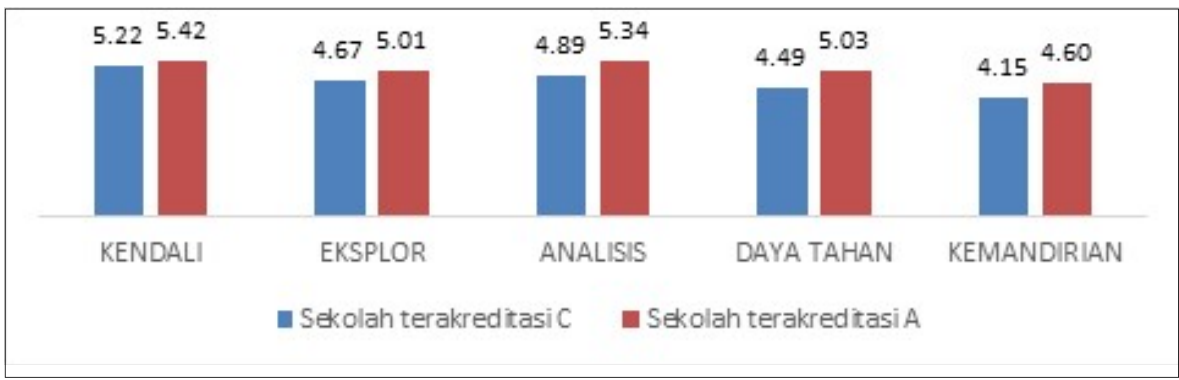

Grafik 12. Daya Juang Siswa pada Sekolah Sampel Kabupaten Bone Bolango 
dianggap mampu secara materi, menghasilkan siswa yang manja dan tidak banyak melakukan upaya untuk memperoleh apa yang diinginkan, dan kurangnya pemberian kesempatan dan challenge untuk melakukan sesuatu secara mandiri. Dapat disimpulkan bahwa pola asuh dari orangtua juga dipengaruhi oleh pekerjaan mereka, dalam hal ini pada upaya penumbuhan kemandirian. Kurangnya pemberian kesempatan dan challenge secara tidak langsung juga menghambat peningkatan daya juang siswa.

\section{Daya Juang Siswa di Sekolah Sampel Kabupaten Bone Bolango}

Berbeda dengan daya juang siswa di sekolah sampel Kabupaten Bantul, daya juang siswa di sekolah terakreditasi C di sekolah sampel Kabupaten Bone Bolango memperoleh skor lebih rendah di semua aspek daya juang dibanding siswa di sekolah terakreditasi A. Skor daya juang siswa di sekolah tersebut umumnya kurang dari 5 kecuali pada aspek kendali diri yang sudah mencapai skor di atas 5 dari maksimal skor 6 . Kendali diri siswa yang baik juga menandakan bahwa siswa sudah memiliki regulasi diri yang baik.

Namun demikian, perbedaan skor daya juang siswa antara sekolah terakreditasi $A$ dan C ini rentang perbedaannya hanya 0.20-0.46. Jika dilihat dari pekerjaan orangtua dari sisi ayah maka terlihat persentase yang hampir berimbang antara orangtua di sekolah sampel terakreditasi A dan C. Uji perbedaan pada jenis pekerjaan ayah terhadap daya juang memperlihatkan bahwa jenis pekerjaan ayah pengaruhnya tidak signifikan. Jenis pekerjaan ayah tidak memberikan pengaruh pada peningkatan daya juang siswa.

Demikian juga kedua orangtua bekerja atau tidak, tidak memberikan pengaruh yang signifikan terhadap daya juang siswa. Adapun ibu siswa di sekolah sampel Kabupaten Bone Bolango di sekolah akreditasi A maupun $C$ lebih dari 50 persen tidak bekerja (sekolah akreditasi A 66.67 persen dan di sekolah akreditasi C 57.50 persen). Sesuai dengan penelitian Sears, dkk. (dalam Raeff, 2006) yang menyatakan bahwa ibu pekerja tidak menyukai ketidakmandirian. Demikian juga, pada hasil di kedua sekolah ini dimana kemandirian siswa memperoleh skor yang paling rendah dari aspek lainnya dan sebagian besar ibu siswa tidak bekerja sehingga tidak mendorong kemandirian pada anak-anaknya.

\section{Perbandingan Daya Juang Siswa di Sekolah Sampel Kabupaten Bantul dan Bone Bolango}

Secara umum, daya juang siswa di kelima aspek daya juang pada sekolah sampel Kabupaten Bantul skornya lebih tinggi dari daya juang siswa di Kabupaten Bone Bolango. Salah satu faktor pendukung tingginya daya juang yaitu local

Tabel 4. Uji Perbedaan Daya Juang Menurut Pekerjaan Ayah

\begin{tabular}{lrrrrrr}
\hline Kelompok Pekerjaan Ayah & $\mathrm{n}$ & $\mathrm{M}$ & $\mathrm{SD}$ & $\mathrm{F}$ & Sig. & Ket. \\
\hline Pegawai Pemerintahan & 12 & 24.58 & 4.85 & 1.825 & 0.084 & $\begin{array}{r}\text { Perbedaan } \\
\text { Tidak } \\
\text { TNI/POLRI }\end{array}$ \\
Pegawai Swasta & 4 & 18.25 & 7.68 & & & Signifikan \\
Wiraswasta & 13 & 25.23 & 2.89 & & & \\
Pekerja Profesional & 21 & 26.29 & 4.29 & & & \\
Pekerja Terampil & 2 & 22.50 & 0.71 & & & \\
Petani/Peternak/Nelayan & 3 & 22.00 & 6.24 & & & \\
Pekerja Kasar & 11 & 24.82 & 3.92 & & & \\
Tidak Bekerja & 24 & 23.50 & 4.70 & & & \\
\hline
\end{tabular}

Sumber: hasil olah data peneliti 
wisdom pada masyarakat yang berada di lokasi rawan bencana yang membuat mereka tidak mudah menyerah dan patah, gotong royong, saling peduli, dan selalu bersyukur dengan kondisi yang menimpa. Ini sejalan dengan hasil penelitian Hidayati (2016) bahwa adanya rasa syukur menjadikan seseorang semakin bersemangat bangkit dari keterpurukan untuk meraih hidup yang lebih baik. Perilaku resiliensi atau kemampuan untuk bangkit dan memperbaiki keadaaan terlihat pada individu yang mengalami keterpurukan. Ini sesuai dengan pendapat Winarsih (2006) bahwa resiliensi adalah kapasitas atau kemampuan mentransformasi diri dengan cara positif. Siswa di lokasi rawan bencana pada penelitian ini memandang musibah sebagai sesuatu yang positif yang membuat mereka termotivasi untuk bangkit dan hidup lebih baik lagi.

Masing-masing perbedaan skor aspek daya juang antara kendali diri, kemampuan eksplorasi dan tanggung jawab, kemampuan membatasi permasalahan, daya tahan dan kemandirian ialah $0.14 ; 0.70 ; 0.42 ; 0.82 ; 1.18$. Dalam skala 100 perbedaan skor ini memiliki range 2.32 hingga 19.71. Perbedaan ini tidak mencolok namun memberikan makna bahwa daya juang siswa di sekolah sampel yang berada di Kabupaten Bantul skornya lebih tinggi daripada daya juang siswa di Kabupaten Bone Bolango. Ada nilai lebih pada daya juang siswa di Kabupaten Bantul yang bisa disebabkan karena pola asuh orangtua, guru, atau faktor pendukung lainnya seperti nilai-nilai yang berlaku di masyarakat. Secara rinci, pada siswa di SD sampel yang berada di Kabupaten Bantul, pada skala kelompok dengan median 5.53 dan standar deviasi 0.12 , tidak ada aspek daya juang yang berada pada kelompok skor tinggi. Sementara aspek kemandirian siswa skornya termasuk dalam kelompok skor rendah. Pada sampel di Kabupaten Bone Bolango, dengan median 4.84 dan standar deviasi 0.36 aspek kendali siswa berada pada kelompok skor tinggi, sementara kemandirian siswa juga berada kelompok skor rendah. Dengan demikian kemandirian siswa di kedua lokasi sampel perlu ditingkatkan, baik melalui peningkatan pola asuh orangtua maupun pola asuh guru dalam menumbuhkan daya juang siswa.

Kemandirian siswa dipengaruhi oleh lingkungan sosialnya. Hasil penelitian Susanti (2013) menyatakan bahwa ada hubungan positif yang signifikan antara dukungan sosial dan daya juang dengan orientasi wirausaha. Semakin tinggi dukungan sosial dan daya juang seseorang semakin tinggi orientasi wirausahanya. Semakin rendah dukungan sosial dan daya juang seseorang, semakin rendah orientasi wirausahanya. Artinya, dukungan sosial meningkatkan daya juang siswa. Di dalam daya juang siswa terdapat aspek kemandirian, yang merupakan bekal untuk berwirausaha, yang skornya masuk dalam kategori baik namun dalam skala kelompoknya termasuk yang paling rendah. Dukungan sosial dapat berupa dukungan moril, materiil (fasilitas), dan spiritual. Fasilitas (materi)
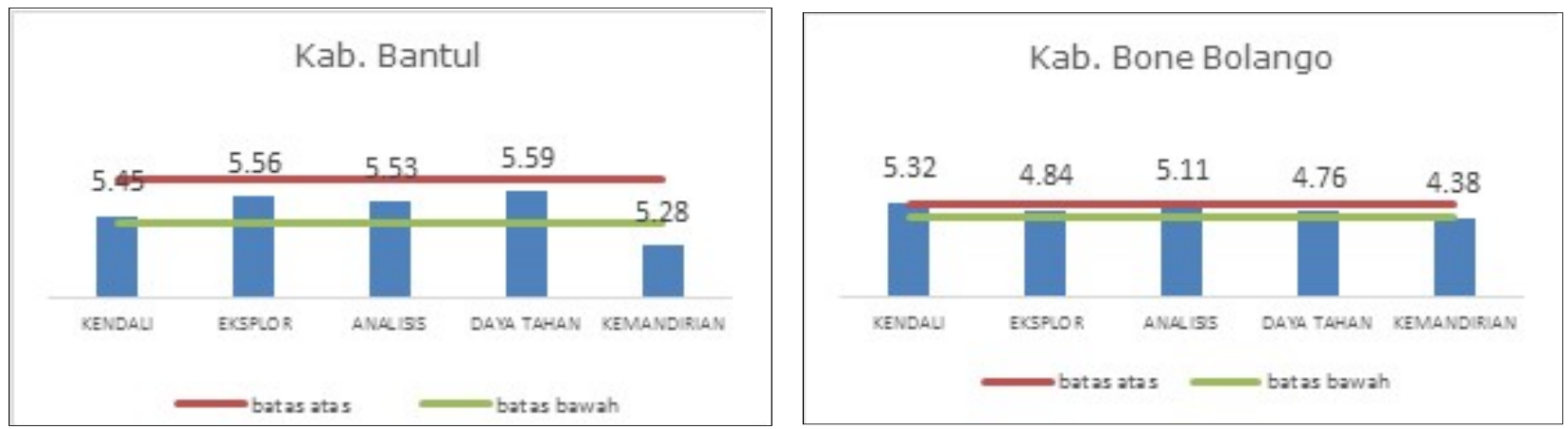

Grafik 13. Gambaran Daya Juang Siswa di Sekolah Sampel di Kabupaten Bantul dan Bone Bolango 
dalam hal ini bisa menjadi pendukung dan penghambat tumbuhnya daya juang. Fasilitas menjadi faktor pendukung manakala dijadikan media yang menumbuhkan nilai positif pada kemandirian. Adapun fasilitas menjadi penghambat manakala dimaknai berbeda oleh individu dan menurunkan kemandiriannya (fasilitas membuat individu ini manja dan kurang berusaha).

\section{SIMPULAN DAN SARAN}

\section{Simpulan}

Dalam semua aspek yang diteliti, baik pola asuh orangtua dan guru maupun aspek potensi daya juang siswa, persepsi siswa di sekolah berakreditasi A lebih baik dari persepsi siswa di sekolah berakreditasi C. Berdasarkan pola asuh orangtua dalam menumbuhkembangkan daya juang siswa, kemampuan kognitif orangtua yang dilihat berdasarkan latar belakang pekerjaannya memengaruhi kemampuannya dalam aspek membimbing anak untuk menganalisa dan membatasi permasalahan. Dengan demikian, latar belakang pendidikan orangtua memengaruhi pola asuh yang diberikan kepada anak mereka.

Kemampuan 'mendengarkan' guru dalam pola asuh yang berkaitan dengan daya juang siswa pada kedua lokasi yang berbeda samasama rendah dalam skala kelompoknya. Sementara kemampuan guru dalam membimbing siswa mengeksplorasi berada pada kelompok skor sedang. Adapun kemampuan guru membimbing siswa untuk menganalisis dan bertindak untuk memecahkan permasalahan yang dialami berada pada kelompok skor sedang cenderung tinggi. Kurangnya kemampuan 'mendengarkan' permasalahan yang dialami siswa menunjukkan kemampuan guru dalam menyimak, memperhatikan, memberikan ketenangan dan penghargaan kepada siswa lebih rendah daripada kemampuan pada aspek lainnya.

Pola asuh orangtua dan guru di Kabupaten Bantul secara bersama-sama memberikan kontribusi kepada penumbuhan daya juang. Sementara secara parsial pola asuh orangtua yang memberikan kontribusi kepada penumbuh- kembangan potensi daya juang hanya pada aspek membimbing untuk mengeksplorasi dan menganalisis permasalahan. Sedangkan secara parsial tidak ada pola asuh guru yang memberikan kontribusi pada penumbuhkembangan keempat aspek daya juang pada siswa. Demikian juga pola asuh orangtua dan guru di Kabupaten Bone Bolango secara bersama-sama memberikan kontribusi secara signifikan pada penumbuhkembangan potensi daya juang siswa. Namun, secara parsial tidak ada pola asuh orangtua yang memberikan kontribusi pada penumbuhkembangan daya juang siswa. Sedangkan pola asuh guru yang memberikan kontribusi hanya pada aspek membimbing untuk bertindak ( $d o$ something).

Persepsi siswa di Kabupaten Bantul terhadap potensi daya juang mereka cukup tinggi dibandingkan dengan persepsi siswa di sekolah sampel Kabupaten Bone Bolango. Pengasuhan orangtua di Kabupaten Bantul sebagai lokasi yang sering dilanda bencana gempa bumi memperlihatkan kecenderungan lebih baik dalam mengobservasi dan kesadaran terhadap kondisi anak, dan memiliki semangat serta motivasi meningkatkan resiliensi anak untuk mampu menyelesaikan masalahnya. Sementara siswa pada sekolah sampel berakreditasi A persepsinya lebih tinggi dari pada siswa di sekolah sampel berakreditasi $\mathrm{C}$ kecuali pada aspek kemandirian siswa di Kabupaten Bantul, dimana persepsi siswa di sekolah sampel terakreditasi A terhadap kemandiriannya lebih rendah daripada siswa pada sekolah sampel terakreditasi C. Pada satu sisi faktor lengkapnya fasilitas yang disediakan orangtua dapat menjadi media bagi kreativitas, motivasi dan kemandirian, namun di lain pihak faktor ini menjadi penghambat manakala kreativitas, motivasi dan kemandirian itu tidak dimunculkan.

\section{Saran}

Peningkatan kompetensi orangtua untuk membimbing anak agar mampu menganalisa dan membatasi permasalahan, dan aspek-aspek daya juang lainnya dapat dilakukan melalui 
peningkatan pengetahuan dan partisipasi orangtua dalam kegiatan yang dilakukan di sekolah. Pengasuhan kepada siswa dalam penumbuhkembangan aspek-aspek daya juang perlu dilakukan secara kolaboratif antara orangtua dan guru sehingga pengasuhan lebih bermakna dan efektif.

Kemampuan guru dalam 'mendengarkan' (menyimak, memperhatikan, memberikan ketenangan dan penghargaan kepada siswa) perlu lebih ditingkatkan melalui pemberian perhatian ketika anak mengalami masalah dengan menyimak pada keluh kesah atau masalah anak, memberikan semangat dan motivasi kepada anak sehingga kendali diri dan percaya diri siswa meningkat. Cara ini juga untuk memberikan rasa diperhatikan, diberikan ketenangan, dan dihargai pada diri siswa sehingga meningkatkan rasa percaya diri, semangat, dan motivasi untuk menghadapi dan memecahkan permasalahan yang dialami, tidak hanya dalam pembelajaran tapi juga dalam pertemanan, di dalam keluarga maupun di masyarakat. Untuk lebih meningkatkan daya juang siswa di sekolah sampel Kabupaten Bantul, orangtua perlu meningkatkan aspek membimbing untuk mengeksplorasi dan menganalisa. Sedangkan pada sekolah sampel di Kabupaten
Bone Bolango, untuk meningkatkan daya juang siswa, pola asuh guru dalam membimbing siswa untuk bertindak mengatasi masalah perlu lebih ditingkatkan.

Orangtua dan guru tidak hanya memberikan fasilitas (media/alat) saja, tetapi juga perlu memberikan bimbingan tentang sikap dan cara untuk menggunakan media yang ada dan memanfaatkan secara lebih baik serta memunculkan inovasi baru dari media tersebut. Sementara tingginya aspek do something pada pengasuhan guru juga perlu ditingkatkan maknanya. Meminta anak untuk melakukan kebaikan dengan berbagai cara tidak akan dipahami dengan baik tujuannya tanpa kita menyampaikan alasan dan makna di balik perbuatan-perbuatan tersebut.

Tingginya pola asuh orangtua dan guru di Kabupaten Bantul sebagai lokasi rawan bencana sedikit banyak dipengaruhi oleh local wisdom masyarakat di lokasi ini. Dimana moto atau slogan gotong royong, motivasi dan semangat untuk tidak mudah menyerah, berserah diri kepada Allah SWT, serta memandang suatu bencana dari sisi yang positif bisa dijadikan Best Practice bagi sekolah lain / di wilayah lain untuk meningkatkan daya juang siswa.

\section{Ucapan Terima kasih}

Ucapan terima kasih penulis sampaikan kepada Dr. Subijanto, M.Ed. (Peneliti Utama) yang telah dengan tekun mengarahkan, membimbing, dan memberi masukan yang konstruktif dalam proses penyelesaian penulisan karya tulis ilmiah ini.

\section{PUSTAKA ACUAN}

Adams, G. \& Dubay, L. 2014. Exploring Instability and Children Well-Being: Insights from a Dialogue among Practitioners, Policy Makers and Researchers. United States: Urban Institute.

Astutik, E.W., Wismanto, Y. B., Goeritno, H. 2012. Studi tentang Regulasi Diri dalam Belajar, Efikasi Diri dan Prestasi Belajar Matematika. Jurnal Prediksi, Kajian Ilmiah Psikologi, II(1), 203-206.

Aswar, S. 2000. Reliabilitas dan Validitas. Yogyakarta: Pustaka Belajar.

Chamidah, A.N. 2009. Deteksi Dini Gangguan Pertumbuhan dan Perkembangan Anak. Jurnal Pendidikan Khusus, 5(2), 83-93.

Cherry, K. 2016. What is a Self Report Inventory?, https://www.verywell.com/what-is-a-self- 
report-inventory-2795587, diakses 11 September 2016.

Desstya, A. 2014. Kedudukan dan Aplikasi Pendidikan Sains di Sekolah Dasar. Jurnal Profesi Pendidikan Dasar, 1(2), 193-200, journals.ums.ac.id/index.php/ppd/article/download/ 1002/679, diakses 18 Oktober 2016.

Dodorico, J.D. 2008. Measuring Personality Constructs: The Advantages and Disadvantages of Self Reports. Informant Reports and Behavioural Assessments, Enquire, 1(1), 75-94. https://www.nottingham.ac.uk/shared/ shared enquire/PDFs/Dodorico J.pdf. diakses 11 September 2016.

Eccles, J.S. 1999. The Development of Children Ages 6 to 14. Journal The Future of Children WHEN SCHOOL IS OUT, 9(2), https://www.princeton.edu/futureofchildren/publications/ docs/09 02 02.pdf. diakses 17 Oktober 2016.

Eccles, J.S. \& Kean, Pamela E. Davis. 2005. Influences of Parents' Education on Their Children's Educational Attainments: The role of Parent and Child Perceptions. London Review of Education, 3(3), 191-204, http://rcgd.isr.umich.edu/garp/articles/eccles05i.pdf., diakses tanggal 9 September 2016.

George, D \& Malery, P. 2003. SPSS for Windows Step by Step: A Simple Guide and Reference II.D Update (4th ed.). Boston: Allys \& Bacon.

Hafstad, G.S., Haavind, H., \& Jensen, T.K. 2011. Parenting After a Natural Disater: a Qualitative Study of Norwegian Families Surviving the 2004 Tsunami in Southeast Asia. Journal of Child and Family Studies, 21(2), 293-302, http://www.ncbi.nlm.nih.gov/pmc/articles/ PMC3304071/, diakses 9 September 2016.

Hasanah, H. 2010. Hubungan antara Adversity Quotient dengan Prestasi Belajar Siswa SMUN 102 Jakarta Timur. Skripsi. Jakarta: Program Sarjana Fakultas Psikologi. Universitas Islam Negeri Syarif Hidayatullah.

Hervira, A. \& Maharani, Y. 2012. Pusat Tumbuh Kembang Anak. Jurnal Tingkat Sarjana Bidang Seni Rupa dan Desain, 1(1), 1-10. s1.fsrd.itb.ac.id/index.php/interior/article/download/ 42/40, diakses 18 Oktober 2016.

Hidayati, I.A. 2016. Daya Juang Pelajar Berprestasi dengan Keterbatasan Kondisi. Tesis. Surakarta: Universitas Muhammadiyah Surakarta, eprints.ums.ac.id/43496/22/ Naskahsip.pdf, diakses 9 September 2016.

Ibda, F. 2015. Perkembangan Kognitif: Teori Jean Piaget. Jurnal Intelektualita, 3, (1),27-38.

Karini, S. M., Herlinawati, S. W., \& Moelyo, A. G. 2009. Gambaran Kasus Psikologi Anak di Klinik Tumbuh Kembang Anak RSUD DR. Moewardi Surakarta. Jurnal Wacana Psikologi, 1(1), 1-9.

Kementerian Pendidikan dan Kebudayaan. 2015. Rencana Strategis Kementerian Pendidikan dan Kebudayaan Tahun 2015-2019. Jakarta: Kementerian Pendidikan dan Kebudayaan.

Lestari, E. 2014. Hubungan Orientasi Masa Depan dengan Daya Juang pada Siswa-Siswi Kelas XII Di SMA Negeri 12 Samarinda Utara. e-Journal Psikologi, 2(3), 314-326.

Mausethagen, S. 2013. A Research Review of the Impact of Accountability Policies on Teachers' Workplace Relations. Elsevier Journal Educational Research Review, 9, 16-33.

Musfirah. 2013. Perkembangan Sosial Anak Usia 11-12 Tahun di Homeschooling Primagama Yogyakarta. Skripsi. Yogyakarta: Fakultas Ilmu Tarbiyah dan Keguruan, Universitas Islam Negeri Sunan Kalijaga Yogyakarta. 
Nur Listiawati, Persepsi Siswa Terhadap Daya Juang Mereka Serta Pola Asuh Orangtua dan Guru Di SD Berakreditasi A dan C di Kabupaten Bantul dan Bone Bolango

Mutammam, M. B. \& Budiarto, M. T. 2013. Pemetaan Perkembangan Kognitif Piaget Siswa SMA Menggunakan Tes Operasi Logis (TOL) Piaget Ditinjau dari Perbedaan Jenis Kelamin. MATHEdunesa, 2(2), 1-6, unesa.ac.id/article/4717/30/article.pdf. diakses 18 Oktober 2016.

Noviarni, S. 2015. Menumbuhkan Daya Juang Anak. http://www.koran-sindo.com/ news.php? $r=3 \& n=8 \&$ date $=2015-12-30$ Edisi 30 Desember 2015, diakses 8 September 2016.

Oktariningtyas, A. M. 2010. Daya Juang: Motivasi Berprestasi. Tesis. Jakarta: Universitas Katolik Atmajaya.

Patenaude, M. 2015. Stress in Low-income Families can Effect Children's Learning. University of Rochester, http://www.rochester.edu/newscenter/stress-in-low-income-families-canaffect-childrens-learning-108182/, diakses 9 September 2016.

Prastowo, A. 2014. Pemenuhan Kebutuhan Psikologis Peserta Didik SD/MI melalui Pembelajaran Tematik-Terpadu. Jurnal Pendidikan Sekolah Dasar (JPSD), 1(1), 1-13. journal.uad.ac.id/ index.php/JPSD/article/download/538/351, diakses 18 Oktober 2016.

Pusat Penelitian Kebijakan Pendidikan dan Kebudayaan. 2015. Kajian Penyelenggaraan Pendidikan untuk Pembangunan Berkelanjutan pada Pendidikan Dasar: Perilaku Menyimpang Pelajar (Laporan Tahun 2015). Jakarta: Puslitjakdikbud.

Raeff, C. 2006. Always Separate, Always Connected: Independence and Interdependence in Cultural Contexts of Development. London: Lawrence Erlbaum Associates Publishers.

Rafiq, H. M. W., Fatima, T.S., Malik, M., Saleem, M. \& Khan, M. A. 2013. Parental Involvement and Academic Achievement: A Study on Secondary School Students of Lahore, Pakistan. International Journal of Humanities and Social Science, 3, (8) 209-223. Sumber: http:// www.ijhssnet.com/journals/Vol 3 No 8 Special_Issue April_2013/22.pdf, diakses 19 Oktober 2016.

Robin, V. 2016. Kokoh dan Tangguh Inilah Wanita Gorontalo, http://hargo.co.id/berita/koko-dantanggu-inilah-wanita-gorontalo.html., diakses 19 Oktober 2016.

Ryan, R. M.,\& Deci, E. 2006. Self-Regulation and the Problem of Human Autonomy: Does Psychology Need Choice, Self-Determination, and Will? Journal of Personality, 74(6), 1557-1586. https://selfdeterminationtheory.org/SDT/documents/2006 RyanDeci SelfRegulationProblemofHumanAutonomy.pdf, diakses 19 Oktober 2016.

Sandstrom, H. \& Huerta, S. 2013. The Negative Effects of Instability on Child Development: A Research Synthesis. United States: Urban Intitute Report: Low Income Working Families Fact Sheet, September 2013. http://www.urban.org/sites/default/files/alfresco/ publication-pdfs/412908-The-Negative-Effects-of-Instability-on-Child-DevelopmentFact-Sheet.PDF, diakses 16 September 2016.

Santos, M. C. J. 2012. Assessing the Effectiveness of the Adapted Adversity Quotient Program in a Special Education School. International Refereed Research Journal, 4(2) www.researchersworld.com/vol3/.../Paper_02.pdf. diakses 19 Oktober 2016.

Setiawan, P. 2015. Perilaku Sosial Siswa Peserta Ekstrakurikuler Karate di Sekolah Dasar Kristen. Bina Harapan Purbalingga. Skripsi. Yogyakarta: Universitas Negeri Yogyakarta.

Sokol, J. T. 2009. Identity Development Throughout the Lifetime: An Examination of Eriksonian Theory. Graduate Journal of Counseling Psychology, 1, (2) 1-11. http:// 
epublications. marquette. edu/cgi/viewcontent. cgi?article $=1030 \&$ context $=$ gjcp, diakses 19 Oktober 2016.

Stoltz, P. G. 1997. Adversity Quotient: Turning Obstacles Into Opportunities. New York: Wiley

Susanti, N. 2013. Hubungan antara Dukungan Sosial dan Daya Juang dengan Orientasi Wirausaha pada Mahasiswa Program Profesi Apoteker Universitas Ahmad Dahlan Yogyakarta. Jurnal Empathy, 2(1), 1-15. http://www.jogjapress.com/index.php/ EMPATHY/article/viewFile/1548/886, diakses 7 September 2016.

Syamsussabri, M. 2013. Konsep Dasar Pertumbuhan dan Perkembangan Peserta Didik. Jurnal Perkembangan Peserta Didik, 1(1), 1-8.

Tatala, M. 2009. The Role of Personal Adjustment to Developmental Crises in Improving Quality of Life. International Journal of Psychology and Counselling, 1(10), 187-193, http:// www.academicjournals.org/article/article 1380358744_Tatala.pdf, diakses 19 Oktober 2016.

Wati, M. 2016. Hubungan antara Perhatian Orangtua dan Sikap Siswa terhadap Layanan Pembelajaran dengan Motivasi Belajar Siswa Kelas VIII SMP Negeri 1 Lendeh Tahun Pelajaran 2015/2016. Skripsi. Program Studi Bimbingan dan Konseling Fakultas Keguruan dan IImu Pendidikan Universitas PGRI Yogyakarta.

Webley, P. \& Nyhus, E. K. 2006. Parents' Influence on Children's Future Orientation and Saving. Journal of Economic Psychology, 27, 140-164. http://home.uia.no/ellenkn/ WebleyNyhus2006.pdf., diakses 19 Oktober 2016.

Willingham, D. T. 2012. Ask the Cognitive Scientist: Why Does Family Wealth Affect Learning? Journal of American Educator, Spring 2012, 33-39. https://www.aft.org/sites/default/ files/periodicals/Willingham.pdf., diakses 19 Oktober 2016.

Winarsih, R. 2006. Kurikulum Kesenian Pasca Gempa SD/MI di daerah Istimewa Yogyakarta. Imaji, 4(2) 157-165., http://eprints.uny.ac.id/4988/1/KURIKULUM KESENIAN PASCA GEMPA SD.pdf., diakses 9 September 2016. 